\title{
Osmanlıda Afet Yönetimi
}

\section{Disaster Management in the Ottoman Empire}

\author{
Murat Koyuncu ${ }^{1}$, Serhat Koyuncu ${ }^{2}$
}

1 Karabuk universitesi tıp fakültesi karabuk eğitim ve araştırma hastanesi acil tıp kliniği. 2Gaziosmanpasa universitesi tıp fakultesi acil tıp anabilim dalı Merkez/Tokat

\section{SAYIN EDITOR}

İnsanlık tarihi kadar eski olan afet: 'Insan ve diğer canlılar için; normal yaşamı ve toplumsal faaliyetleri kesintiye uğratan, toplumda fiziksel, sosyal, kültürel ve ekonomik kayıplara neden olan ve etkilenen topluluğun üstesinden gelemediği doğa veya insan kaynaklı bir olgudur' olarak tanımlanır. Her türlü deprem, sel veya yangın afet olarak değerlendirilemez. Afet için ön koşul doğal olaylardan etkilenen topluluğun, kendi imkanları ile üstesinden gelememesidir. Afetlerin olması insanlığın afetlere karşı mücadelesini de beraberinde getirirken, bilimin de gelişmesine etkili olduğu kaçınılmaz bir gerçektir. Ayrıca göçlere neden olarak nüfus hareketliliğine, siyasi ve etnik haritaların değişmesine de neden olmuşlardır. Türk tarihinde de Anadolu'ya göçün kökeninde muhtemel doğal afet varlığı tarihçilerin hem fikir olduğu bir konudur $(1,2)$.

Afet, afet yönetimini beraberinde getirir. Afetlerin yıkımının ve sekonder zararları azaltılması amacıyla, afet öncesi hazırlık, koruma, kurtarma, tıbbi yardım ve yeniden inşa sürecini içeren çalışmalara afet yönetimi adı verilir. Yani olağan dışı durumların üstesinden gelebilme çabası olarak adlandırılabilinir $(1,2)$.

Ülkemiz dünyanın en çok deprem görülen bölgelerinden birisi olduğu kaçınılmaz bir gerçektir. Tarihte yıkıcı büyük depremler meydana gelmiş ve bundan sonrada meydana gelecektir. Osmanlıdan günümüze, halkın ve yöneticilerin afetlere bakış açısı, zarar meydana geldikten sonra, oluşan hasarı gidermeye yönelik çalışmalarla sınırlıdır. Maalesef ki afeti önleme veya afet ile oluşabilecek zararları azaltma yönünde önlem ve çalışmalara önem verilmemiştir Son yıllarda ülkemizde afet yönetimi konusunda oldukça ilerleme kaydedilmiştir. Yani ülkemizin başına gelen afetlerden ders çıkarılmış ve 2009 yılında Başbakanlığa bağlı, Afet ve Acil Durum Yönetimi Başkanlığı kurularak, afet yönetimi tek çatı altında toplanarak, planlı bir çalışma başlanmıştır (3).

Anahtar Kelimeler: Afet yönetimi, Osmanlı İmparatorluğu, Disaster Management, Ottoman Empire

Corresponding Author: Serhat KOYUNCU

Address: Gaziosmanpaşa Üniversitesi, Tıp Fakültesi, Ali Şevki

Erek Yerleşkesi, Acil Tıp AD, Merkez/TOKAT .

Başvuru Tarihi/Received: 20-07-2016 
Ülkemiz sınırları içerisinde, tarihindeki afetlerle ilgili ilk bilgiler, M.S. 1488 yılına ait medeniyetin beşiği, üç büyük imparatorluğa başkentlik yapmış olan İstanbul ile ilgilidir. Osmanlı dönemindeki kayıtlarda ise Sultan 2. Beyazıt zamanında (1488 yılında) büyük bir deprem yaşanmıştır. İkincisi ise 1509 yıllarında küçük kıyamet (Kıyamet-i Suğra) adı verilen ve 45 gün süren deprem olarak tarih kayıtlarına geçmiştir. Hatta Sultan 2. Beyazıt bu nedenle Edirne'den ülkeyi yönetmiştir. Bu depremden sonra İstanbul'da evler depreme daha dayanıklı olduğu için ahşaptan yapılmaya başlamış ancak bu seferde 1782 yılında büyük hasar bırakan ve uzun süre söndürülemeyen bir başka afet; İstanbul Büyük Yangını yaşanmıştır (3).

Osmanlı dönemindeki afet yönetimi ile ilgili bilgilerimiz ise deprem ve yangınlar sonrası oluşan büyük yıkım sonrası padişah fermanı ile halka yapılan acil yardım ve konutları içermektedir. Bununla ilgili ilk yazılı örnek, Eylül 1509 yılındaki İstanbul depremi sonrası ile ilgilidir. Yaklaşık 13.000 insanın öldüğü, 109 cami ve 1047 yapının yıkıldığı bu depremden sonra, II. Beyazıt çıkardığı bir fermanla, yeniden ev yapmak amacıyla aile başına 20 altın bağışta bulunmuş ve harap olan tarihi kentin yeniden imarı için 50.000 usta görevlendirilmiştir. Aynı fermanla 14-60 yaşları arasındaki erkeklerin inşaat işlerinde çalışmaları zorunlu kılınmış, bu sayede yeniden imar hızlandırılmıştır. Deniz kenarındaki dolgu zeminler üzerine ev yapmak yasaklanmış ve ahşap-karkas (bağdadi) ev yapımı teşvik edilmiştir (3).

Afet yönetimindeki en önemli basamak ise oluşan zararı azaltabilmek ve halka acil yardım ulaştırabilmek amacı ile 1868 yılında kurulan Hilal-i Ahmer Cemiyetidir. Bu maddi ve tıbbi yardım organizasyonu Cumhuriyet döneminde Kızılay Derneği adını almıştır (3).
Anadolu'da da meydana gelen ve kayıtlarda söz edilen depremlerden biri de 1883 yılında Çeşme ve Urla bölgesinde olmuştur. Bu depremde yıkıcı olmuş nerdeyse köyler haritadan silinmiştir. Yerel ve merkezi yöneticiler bu deprem sonrası oldukça başarılı bir yönetim sergilemişlerdir. II. Abdulhamid tarafından İzmir askeri komutanı Ferik Salih Paşa, yaverlerinden Miralay Süleyman bey, Aydın valisi Naşid paşa görevlendirilmiştir. Bu yöneticiler afet sonrası oldukça uyumlu bir çalışma göstermişlerdir. Ayrıca Müslüman dini önderlerinin yanında Rum, Ermeni ve Musevi dini liderler, bölgenin önemli şahsiyetleri de yöneticilerle uyum içinde çalışmışlardır (4).

Depremde en çok etkilenen Reisdere köyü, Ferik Salih Paşa tarafından yardım merkezi olarak seçilmiştir. Buranın seçilmesinde stratejik önemi vardır. En çok etkilenen yer olmasının yanında afet bölgesinin tam ortasında ve denize yakınlığı da bu tercihte etkili olmuştur. Osmanlı merkezi ve mahalli yöneticileri, Çeşme ve Urla depremi sonrasında başarılı bir afet yönetimi örneği sergilemiştir. Afet yönetiminde merkezi hükümet tarafından özel olarak görevlendirilen yetkililer, mahalli yönetime nazaran daha etkin rol üstlenmişlerdir. Merkezi hükümet tarafından görevlendirilen yetkililer, mahalli hükümet temsilcileri ve afet bölgesindeki dini temsilcilerinin birbirleriyle uyum içerisinde ve gayretle çalıştıkları görülmüştür. Depremzedeler için 25 gün gibi çok kısa bir sürede barakaların inşasının tamamlanarak 25-30.000 civarındaki afetzedenin barınma problemlerinin çözülmesi yadsınamayacak bir başarı olmuştur. Ayrıca ayni ve nakdi yardımların bir koordinasyon dâhilinde tek elden dağıtılması depremzedeler arasında adil bir paylaşımı sağlamıştır. Bu arada Sultan II. Abdulhamid, özel temsilcisi olarak gönderdiği Yaver Miralay Süleyman Bey vasıtasıyla verdiği mesajlar ve özel hazinesinden dağıttığı önemli miktarda para 
ile afetzedelerin yanında olduğunu hissettirmiştir (4).

Osmanlı imparatorluğunda afet ve afet sonrası kayıtlardan biri de 1897 yılında Uşak kasabasında ortaya çıkan yangındır. Bu olayda yapıların birbiri ile bitişik ve ahşap olması nedeni ile yangın tüm kasabaya yayılmış ve neredeyse kasaba tamamen kül olmuştur. Bu kadar büyük yıkım olmasının en büyük nedeni sokakların dar olması, yeterli su kaynaklarının bulunmaması, tulumbacılar (itfaiye teşkilatı) yeterli olmaması en büyük etkendi (5).

$\mathrm{Bu}$ yangın sonrası imparatorluk yöneticileri afet yönetimi konusunda ilk çalışmaları başlatmıştır. Öncelikle çok hantal olan bürokratik düzen Yıldız Sarayı'nın müdahalesi ile daha işlevsel hale getirildi. Afetzedeler yardımların dağıtımı, barınma ve beslenme problemlerinin çözümü direk Yıldız Sarayından yönetilmeye başlandı. Afet bölgesindeki halka vergi muafiyeti sağlandı. Afetzedeler tıbbi yardımlar daha organize hale getirildi. Uşak kasabasının yeniden imarı için çalışmalara oldukça hızlı bir şekilde başlandı. Yangından zarar görenlerin zaruri ihtiyaçlarını temin ve eşgüdümü sağlamak amacıyla kaymakam nezaretinde Osmanlı'da bir ilk olan ve bu günkü manada bir kriz masası, Tehvîn-i İhtiyaç Komisyonu adıyla kuruldu. Uşak yangını Osmanlıda afet yönetimi açısından ilklere sahne olmuştur. Her ne kadar politik baskılar çok olsa bile yardımların dağıtılması, hastalıklara müdahale ve kentin yeniden inşası açısından en önemli ilk çalışmaların yapılması açısından önem arz eder (5).

Afetler sonucu yapılaşma ve şehirleşmenin kurallara bağlanması ihtiyacı duyulmuştur. Tanzimat ile başlayan batılılaşma akımı, afetlerin şehirlerde yeni yapılanma zorunluluğunu göz önüne sermesi ile Avrupa tarzı kentleşme düşüncesi Osmanlı yöneticilerinde ortaya çıkmıştır. Bu akımın neticesi 1848 yılında 'Ebniye Nizamnamesi' çıkarılmış ve İstanbul içerisinde yapılaşmalara bazı düzenlemeler getirilmiştir. Bundan yaklaşık $30 \mathrm{yıl}$ sonrada bu kurallar tüm imparatorluk sınırları içerisindeki yerleşim yerlerine yaygınlaştırılmıştır. Ebniye Nizamnamesinin 20. maddesine göre, bir mahallede ondan fazla hanenin yanması hâlinde, yanan mahallenin tarla şeklinde tesviye ve yeniden taksim edilmesi ve bu taksimatın modern kent pratiğine uygun olarak yapılması ön görülmüştü. Ancak bu kanuna uygun olarak çalışmaya başlayan mimar ve ustalar saraya şikayet edildi. Şikayetlerin artması üzerine yeniden düzenleme çalışmaları iptal edildi ve mimar ve ustalar görevden alındı. Politik baskıların oldukça fazla hissedildiği bir süreç yaşandı (2, 5).

Tarih sadece savaşlar, antlaşmalar değildir. Sosyal bir tarih de vardır. Tarih incelenip gelecek için ders alınmalı ve bu alınan ders doğrultusunda sosyal hayatı ve geleceği şekillendirilmelidir. tarihinden ders alıp geleceğini yönlendiren toplumlar her zaman başarılı olmuşlardır. Ancak sadece tarihini okuyup ders çıkaramayan toplumlarda geri kalmaya mahkum olmuşlardır.

Afet alanında geçmiş olayları inceleyip, dersler çıkarıp buna göre afet yönetimi oluşturmamı gerektiği yadsınamaz bir gerçektir. 19. yy da başladığımız afet yönetimini maalesef ki gereken dersi çıkaramadığımız için Erzincan ve Düzce depremlerinde başarısız bir yönetim sergilerken,Van depreminde başarılı olunması, geçmiş başarısızlıklardan çıkarılan dersin önemini göstermektedir.

Sonuç olarak tarihi doğru okumayı ve gereken dersi çıkarmayı bilmemiz gerekir ki bu sayede büyük önden Mustafa Kemal'in işaret ettiği muasır medeniyetler seviyesine çıkabilelim 


\section{KAYNAKLAR}

1. Işık Ö, Aydınlıoğlu HM, Koç $S$, Gündoğdu O, Korkmaz G, Ay A. Afet Yönetimi ve Afet Odaklı Sağlık Hizmetleri. Okmeydanı Tıp Dergisi 2012;28(2):82-123

2. Uluğ A. Nasıl Bir Afet Yönetimi? TMMOB İzmir Kent Sempozyumu. 2009. İzmir

3. Selçuk Biricik A. Yeryuvarı'nda Doğal Olaylar ve Âfetler.Marmara Coğrafya Dergisi. 2001;3(1):7-26
4. Satılmış S. Osmanlı'da Bir Afet Yönetimi Örneği: 1883 Çeşme Ve Urla Depremi. History Studies. 2012;4(1): 503-527

5. Çakmak B. Geç Dönem Osmanlı İmparatorluğu'nda Afet Yönetimi: 1894 Büyük Uşak Yangını . Hacettepe Üniversitesi Türkiyat Araştırmaları Dergisi, 2011;(15:63-90 